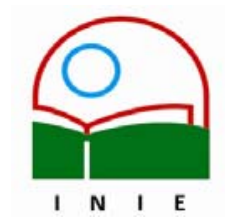

Universidad de Costa Rica

Facultad de Educación

Instituto de Investigación en Educación

ACTUALIDADES INVESTIGATIVAS EN EDUCACION

\title{
THE EFFECT OF EXPLICIT VOCABULARY TEACHING ON VOCABULARY ACQUISITION AND ATTITUDE TOWARDS READING
}

\author{
Leyla Hasbún Hasbún ${ }^{1}$
}

\begin{abstract}
This study examines the effects of explicit vocabulary teaching on vocabulary acquisition and on attitude towards reading in an EFL class. Vocabulary exercises following the Lexical Approach (Lewis, 1993, 1997, 2000) were designed to supplement a college reading comprehension course, and several reading strategies were systematically practiced. Statistical analyses revealed that the students acquired the vocabulary. In addition, at the end of the term, learners claimed that knowing more words had made them better readers, and the final evaluation of the course showed that their attitude towards reading had greatly improved.
\end{abstract}

Key words: READING COMPREHENSION/ VOCABULARY TEACHING/ VOCABULARY ACQUISITION/ LEARNING STRATEGIES/

Resumen: El presente trabajo investiga los efectos que produce la enseñanza explícita del vocabulario tanto en la adquisición de dicho vocabulario como en la actitud de un grupo de estudiantes de inglés como lengua extranjera hacia la lectura. Se diseñó un grupo de ejercicios siguiendo el Acercamiento Léxico (Lewis, 1993, 1997, 2000) para complementar un curso universitario de comprensión de lectura. Además, en forma sistemática, se utilizaron varias estrategias de lectura en clase. Los análisis estadísticos revelaron que los aprendices habían adquirido el vocabulario. Al finalizar el semestre, los estudiantes afirmaron que el conocimiento de nuevas palabras los había hecho mejores lectores, y la evaluación del curso reveló que la actitud de los estudiantes hacia la lectura había mejorado en forma significativa.

Palabras claves: COMPRENSIÓN DE LECTURA/ ENSEÑANZA DE VOCABULARIO/ ADQUISICIÓN DE VOCABULARIO/ ESTRATEGIAS DE APRENDIZAJE/

Change is a distinctive characteristic of the world of foreign or second language teaching and learning. Teaching practices have evolved as linguists have begun to understand the complex processes of language acquisition. Techniques have improved as teachers have gained insight into what kinds of courses and lessons might both accelerate language acquisition and make these courses and lessons more enjoyable. Above all, striking changes have taken place in the language classroom, as learners have felt empowered to take control of their own learning. One of the most influential changes of the last decade of the twentieth century was the shift of focus, proposed by many theorists and practitioners,

\footnotetext{
Doctora en Lingüística Aplicada de la Universidad de Indiana y Licenciada en Literatura Inglesa de la Universidad de Costa Rica. Profesora Catedrática de la Universidad de Costa Rica y Directora del Programa de Posgrado en la Enseñanza del Inglés. Imparte cursos de grado y posgrado en la Escuela de Lenguas Modernas. Ha publicado en el área de la adquisición del inglés y del español como segundo idioma, la sociolingüística y la formación de profesores.
}

Correo electrónico:Ihasbun@cariari.ucr.ac.cr

Artículo recibido: 18 de octubre, 2005

Aprobado: 12 de diciembre, 2005 
from grammar as the central anchor of language teaching to the lexicon. David Wilkins (cited in Thornbury, 2002) aptly sums up this change as follows: "Without grammar very little can be conveyed; without vocabulary nothing can be conveyed."

After the publication of The Lexical Approach by Michael Lewis in 1993, there was an evident revival of interest in vocabulary acquisition. What this author suggests in his book is definitely compatible with the claims of the communicative approaches; however, in Lewis' proposal there seems to be a greater emphasis on the meaning and use of the different language items. He argues that "the Lexical Approach is not a new all-embracing method, but a set of principles based on a new understanding of language." Since Lewis' claims make so much intuitive sense, the main goal of the present study is to investigate whether the kinds of activities and strategies proposed by Lewis (1993, 1998, 2000) and others like Nation, (1994, 2001), and Thornbury (2002) facilitate vocabulary acquisition and whether explicit teaching and incidental acquisition of vocabulary make EFL reading more effective.

\section{Review of the literature}

\subsection{What to teach}

Most people think of vocabulary as lists of words. However, besides single words, vocabularies include numerous multi-word items. The review of the literature reveals that we do not have a universal definition of the term vocabulary. For instance, Folse (2004, pp. 2-9) discusses set phrases, variable phrases, phrasal verbs and idioms. Thornbury $(2002$, p. 6) mentions the term "lexeme" which he defines as "a word or group of words that function as a single meaning unit." Additionally, he talks about lexical chunks, which vary in the degree in which they can be fixed or idiomatic, sentence frames, and phrasal verbs. Despite the differences in terminology, it is obvious that the above-mentioned classifications highlight the fact that words require their neighboring words to express meaning.

Learners need to keep in mind that these multi-word units are necessary if natural communication is to happen. For example, in order to acquire phrasal verbs, students need to understand their form, their meaning and their use. Larsen-Freeman (2001, p. 254) mentions that knowing the form of a phrasal verb includes knowing whether it is followed by a particle or by a preposition, whether it is transitive or intransitive, whether it is separable or not, and what stress and juncture patterns are used. Knowing the meaning encompasses literal, figurative and multiple meanings. Finally, knowing the use covers understanding the fact that phrasal verbs are part of informal discourse and that they operate by the principle of dominance. For example, if learners encounter the verb "look" in a reading passage and 
have trouble understanding what it means, their chances of guessing the meaning from context are minimized if they ignore the particle or preposition that follows it. If then they decide to look it up in a dictionary, they will not necessarily find the definition that fits the context since "look" is a good example of what is called a de-lexicalized verb. Its meaning changes depending on the particle or preposition that follows it (for a discussion of the topic, see Lewis, 1993, p. 143). The following table illustrates the complexity of the problem. It presents only the most frequent of the possible phrasal verbs starting with the verb "look" that Cowie \& Mackin (1993) include in their dictionary.

Table 1: Phrasal verbs with the verb "look"

\begin{tabular}{|l|l|}
\hline \multicolumn{2}{|c|}{ Look } \\
\hline look about/around & Examine \\
\hline look after & Be responsible for \\
\hline look ahead & Think about events in the future \\
\hline look back & Return in one's thoughts \\
\hline look for & Try to find \\
\hline look on & To be a spectator \\
\hline look out & Take care, beware \\
\hline look up & Try to find, especially in a work of reference \\
\hline look up to & Regard with respect \\
\hline
\end{tabular}

Knowing a word also implies knowing its collocations, that is, the words with which it is most likely to occur in speech or in writing. In other words, the term collocation refers to the combinations of words that are natural and normal to native speakers (For a discussion of this topic see Lewis, 1993, 1997 and 2000; Nation, 2001; Thornbury, 2002). Knowledge of typical collocations gives learners power. Not only will they avoid making mistakes, but they will also sound more native-like because fluent and appropriate language use requires collocational knowledge. The following table summarizes the most frequent collocates of the noun "problem" provided by Benson, Benson \& Ilson (1997) in their dictionary. 
Table 2: Collocations

\begin{tabular}{|c|c|c|c|}
\hline \multicolumn{4}{|c|}{ Problem: An unsettled question } \\
\hline cause, create, pose, present & \multirow{7}{*}{$a(n)$} & $\begin{array}{l}\text { acute, daunting, difficult, grave, } \\
\text { major, pressing, serious, insoluble, } \\
\text { insurmountable }\end{array}$ & \multirow{7}{*}{ problem } \\
\hline have & & $\begin{array}{l}\text { complex, complicated, involved, } \\
\text { knotty, perplexing, thorny }\end{array}$ & \\
\hline be, constitute & & delicate, ticklish & \\
\hline $\begin{array}{l}\text { address, explore, bring up, } \\
\text { raise, confront, face }\end{array}$ & & minor, petty & \\
\hline $\begin{array}{l}\text { attack, come to grips with, } \\
\text { deal with, grapple with, tackle }\end{array}$ & & $\begin{array}{l}\text { attitude, drinking, emotional, } \\
\text { physical, psychological, social }\end{array}$ & \\
\hline lick, resolve, settle, solve & & \multirow[t]{2}{*}{ perennial } & \\
\hline avoid, sidestep & & & \\
\hline
\end{tabular}

Another issue to address is the cumulative nature of the process of vocabulary learning. Vocabulary experts (Anderson, 1999; Nation, 2001) claim that learners need multiple encounters with a new word in order to truly understand it and learn it. Furthermore, it is important to consider what information is required to have native-like mastery of a word.

Knowing a word involves a wide range of understandings and skills related not only to the form but also to the meaning and use of that particular word. Therefore, all possible aspects cannot be acquired at once. Learners tend to acquire prototypical meanings and uses first and, as they advance, they begin understanding others that are more marked, provided they get enough exposure or comprehensible input. For instance, it is not realistic to expect learners to acquire all the possible collocates for the noun "problem" exemplified in Table 2. What teachers can reasonably expect is for learners to acquire the prototypical verbs and adjectives that co-occur with it, and perhaps, be able to recognize the rest.

Lewis (1993: 3) proposes that, in the initial stages of language acquisition, the role of sentence grammar should be decreased, favoring instead an increase in the role of what he calls "word grammar," that is, the patterns in which any given word may occur. This includes close attention to issues such as collocations mentioned above and cognates, that is, words that have similar forms in two languages. Thornbury $(2002$, p. 28) provides additional examples of word grammar: knowing whether an English verb is followed by an infinitive or by a gerund o whether a phrasal verb is separable or not. Consequently, mastering words 
implies coping with the combination of words into phrases, sentences, and texts, namely, being aware of the fact that in English, as in any other language, there are many fixed, identifiable, constructions. Lewis also favors the emphasis of text grammar, that is, those features of the language that apply beyond the mere sentence level such as supra-sentential linking. Many other authors have discussed the importance of context (Johns, 1997; Nagy, 1997; Read, 2000; Nation, 2001; Meara, 2002). They claim that speakers cannot assign any meaning to words in isolation. Meaning emerges from the connection between words in a context. Meara (2002, p. 400) points out that "context can radically change the meaning of words, making familiar words opaque, and unfamiliar words completely transparent."

Another important issue to consider is the many constraints on the use of words. Language acquisition includes knowing when to use a lexical item. In my teaching experience, I have often noticed that learners pick up many words or fixed expressions from movies, cable television, or popular teen magazines. Many informal expressions and others whose uses are highly restricted to very intimate situations or only appropriate when talking with close friends of a similar age group are used by learners in class discussions or in assignments. From the context in which they occur, it is obvious that the learners know their meaning. What they do not know is that, even though those lexical items are high frequency words in many movies or sitcoms, they are definitely not appropriate in many situations. A case in point is the use of swear words to either emphasize what one means or to insult someone or something. Another constraint is frequency. For instance, learners need to be made aware of the fact that they might find cognates in the L2 whose frequency of occurrence is very different from the frequency of the equivalent word in their L1. To cite an example, although the English verbs "explain" and "explicate" are synonyms, they definitely vary in relation to frequency and level of formality. The fact that "explicate" is closer to the Spanish verb "explicar" might lead learners to choose the wrong verb. Nation (2001, p. 58) believes that

most constraints on use are best dealt with by discussion and explicit cross-cultural comparison. The frequency constraint is best dealt with by familiarity with the language, although in the early stages of learning, direct information about whether a word is commonly used or not is useful.

\subsection{How to teach vocabulary}

Thornbury (2002) discusses several techniques and procedures a teacher might choose to help learners acquire new vocabulary items. The underlying premise is that 
sometimes there is a need for the instructor's direct intervention in the teaching of selected vocabulary items. Thornbury admonishes teachers to consider important issues such as how many words to present at a time, whether to present the meaning or the form of a word first, and whether to use translation, as opposed to using some type of visual or verbal illustration. This reflection will enable teachers to make appropriate choices. Thornbury adds that the procedure a teacher follows to help learners become aware of how the grammar of a given word works is very similar to the one learners use to understand collocations. The key is to provide learners with rich data and to guide them to pay attention to patterns and to notice.

Since Lewis (1997) claims that most of the activities used in the Communicative Approach are compatible with the Lexical Approach, then what teachers need to do is adapt activities so that the tasks have a clear lexical focus. To achieve this goal, Lewis (1997, p.205) points out that teachers should do the following:

- Consciously take every chance to expand the learners' phrasal lexicon.

- Develop learners' awareness of word-grammar as well as sentence grammar.

- Highlight Fixed Expressions and prototypical examples, so ensuring learners have maximum benefit from the language they meet.

- Encourage accurate observation and noticing by learners, but without excessive analysis.

- Use many different ways to increase learners' awareness of the value of noticing, recording and learning multi-word items.

- Encourage learners to keep a well-organized lexical notebook.

- Encourage lexical, but not structural, comparison between L1 and L2.

- Help learners to hear and learn language in multi-word units.

- Talk more informally, but in a carefully controlled way, with your class.

- Tell simplified anecdotes (true or otherwise): increase carefully-controlled teacher talking time.

- Take a global, holistic view of pronunciation.

- Value successful language at all times, even if it is not formally accurate.

Furthermore, in the preface to his second book Implementing the lexical approach, Lewis (1998, p. 3) argues that

implementing the lexical approach in your classes does not mean a radical upheaval, likely to upset colleagues, parents and learners. On the contrary, if introduced with 
thought and sensitivity, its introduction will be almost invisible, involving perhaps 20 or even 50 small changes in every lesson, each in itself unremarkable, but the cumulative effect will be more effective teaching and more efficient learning.

\subsection{Types of activities}

Lewis (1998: 86-141) proposes a series of tasks carefully constructed on lexical principles. The following is a list of the most important:

- In de-contextualized gapped sentences, the gap should not occur in the topic element.

- Since the quantity and quality of the input influences progress the most, exercises must be based on highly probable, useful examples.

- If exercises are to teach rather than test, learners must recognize some answers and deduce others by a process of elimination, using linguistic clues, the group's shared knowledge, and a small element of plain guesswork.

- When working with collocations, words should be presented in descending order of information content. This would make the first examples the strongest collocations.

- Collocations should be presented in context. It is not a good idea to have learners match de-contextualized words.

The following is a list of the basic exercise types:

- Identifying chunks. This is a fundamental skill which aids language acquisition

- Matching: Parts of collocations, expressions, lines of stereotypic dialogue

- Completing: Blank spaces correspond to partner words from fixed collocations

- Categorizing: Use categories learners perceive or follow some guideline suggested by the teacher.

- Sequencing: Learners are given expressions or verbs and are asked to put them in the most likely order.

- Deleting: Learners circle the word that does not belong.

\section{Research questions}

The following research questions guided the present study:

1. Is there significant vocabulary development if vocabulary is explicitly and systematically taught in a reading course? 
2. Is there improvement in the learners' attitude towards reading if they are taught vocabulary explicitly and are provided with strategies to read faster and more fluently and understand better?

\section{Method}

\subsection{Participants}

Twenty-five college students, 17 females and 8 males, took part in this study. All of them are native speakers of Spanish and are majoring in either English or English Language Teaching at a large public university in Costa Rica. At the time of the study, they were taking LM-1246, Reading Comprehension, a required second-year course. The level of proficiency is described as intermediate. Of all the sections of this course on that particular semester, the group with the highest average GPA (grade point average) was the one that participated in the study. From the comments of previous groups in final evaluations and reading journals, the researcher knew that students at this level tend to be very aware of the importance of word choice and often complain about their lack of vocabulary.

\subsection{The course and the textbook}

There are two main components in the reading course. The first one is an intensive reading program, which takes place in the classroom, where the learners have the opportunity to apply different reading strategies. The textbook chosen for the intensive reading program is Active: Skills for Reading 4 (2003) by Neil J. Anderson, which is intended for high intermediate students. The author's understanding of the complex process of reading is summarized in the title of the textbook, ACTIVE, which is an acronym for

- Activate prior background knowledge

- Cultivate vocabulary

- Teach for comprehension

- Increase reading fluency

- Verify strategies

- Evaluate progress

The textbook explicitly teaches ten words per lesson. The Teacher's Manual (2003) explains that in every chapter, there is a vocabulary comprehension section that includes exercises such as matching vocabulary items to definitions, identifying the odd word out in a 
sequence, and recognizing the meaning of words in context. In a separate section, learners are encouraged to use the vocabulary items in alternative contexts. They work with cloze sentences and gap-filling activities or give alternative examples to illustrate understanding of meaning and nuance. Finally, there is a vocabulary skill section to provide explicit instruction on the use of strategies that will help learners improve their capacity to understand and hopefully acquire new vocabulary items. These strategies include identifying homophones, using synonyms and antonyms, recognizing root words, using prefixes and suffixes, organizing vocabulary into word families, and using phrasal verbs.

The second component of the course is an extensive reading program. It takes place outside the classroom, and reading for pleasure is the main goal. For the extensive reading program, the learners read at least four novels of their choice. They are about 350 pages long. Examples of popular titles that semester were The Lonely Bones by Alice Sebold and Five Patients by Michael Crichton.

\subsection{Materials}

On the first day of class, the instructor gave the students a multiple-choice vocabulary test. There were 48 items that comprised two groups of words: 3 words selected from each of the 13 chapters studied during the semester for a total of 39 words and 3 words taken from 3 chapters that were not studied for a total of 9 words. It was assumed that all the words had a similar level of difficulty.

Learners were told that the purpose of the exam was to determine vocabulary gains throughout the semester. They were discouraged from guessing and were assured that the results of that test in no way would influence their final grade. The instructor scored the exams but never gave them back to the students or provided any type of feedback. On the last day of the semester, the same exam was administered. A week later, the instructor met with the students on an individual basis and let them know how much they had improved.

On the first day, the students also completed a questionnaire whose aim was to determine the learners' reading preferences and attitudes towards reading. Finally, on the last day of classes, they filled out a questionnaire to evaluate their work.

\subsection{Procedure}

During the semester, the instructor taught 13 chapters, following the general guidelines provided by the textbook. Special attention was paid to the vocabulary section. Furthermore, for every chapter the instructor designed additional exercises of the types suggested by Lewis 
(1993, 1997, and 2000), Nation (1994, 2001) and Thornbury (2002) to promote vocabulary acquisition. These activities included word families and parts of speech relations, collocations, phrasal verbs, cognate awareness, and dictionary use. An effort was made to provide multiple contexts for the words and multiple encounters with them.

\section{Analysis}

After the treatment described above, the results of the pre and posttest were tabulated, and several $t$-tests were performed to determine whether there was a significant difference between the scores. The first set of tests examined the group's acquisition of each item. The other 3 compared the performance of each of the subjects in the pre and posttest.

\section{Results and Discussion}

\subsection{Statistical Analysis}

Table 3 summarizes the raw data corresponding to the pre and posttests. The first column presents the item, the second the number of students who got that items wrong on both tests, the third column the number of students who got it wrong the first time but correct the second, the fourth the number of students who got it correct the first time but incorrect the second, and the last column the number of students who got it correct on both tests.

Table 3: Summary of the results of the pre and posttest by test item

\begin{tabular}{|l|c|l|l|l|l|l|l|l|}
\hline Vocabulary Item & \multicolumn{3}{|l|}{ Both Wrong } & \multicolumn{2}{l}{$\begin{array}{l}\text { Wrong } \Rightarrow \\
\text { Correct }\end{array}$} & \multicolumn{2}{l|}{$\begin{array}{l}\text { Correct } \Rightarrow \\
\text { Wrong }\end{array}$} & \multicolumn{2}{l|}{ Both Correct } \\
\cline { 2 - 11 } & Raw & $\%$ & $\begin{array}{l}\text { Raw } \\
\text { Score }\end{array}$ & $\%$ & $\begin{array}{l}\text { Raw } \\
\text { Score }\end{array}$ & $\%$ & $\begin{array}{l}\text { Raw } \\
\text { Score }\end{array}$ & $\%$ \\
\hline recipient & 1 & $4 \%$ & 9 & $36 \%$ & 0 & $0 \%$ & 15 & $60 \%$ \\
\hline enhanced & 0 & $0 \%$ & 21 & $84 \%$ & 0 & $0 \%$ & 4 & $16 \%$ \\
\hline think on your feet & 2 & $8 \%$ & 12 & $48 \%$ & 0 & $0 \%$ & 11 & $44 \%$ \\
\hline rapport & 0 & $0 \%$ & 11 & $44 \%$ & 1 & $4 \%$ & 13 & $52 \%$ \\
\hline ultimate & 0 & $0 \%$ & 7 & $28 \%$ & 2 & $8 \%$ & 16 & $64 \%$ \\
\hline expertise & 0 & $0 \%$ & 5 & $20 \%$ & 0 & $0 \%$ & 20 & $80 \%$ \\
\hline relinquish & 2 & $8 \%$ & 17 & $68 \%$ & 0 & $0 \%$ & 6 & $24 \%$ \\
\hline perpetrator & 1 & $4 \%$ & 7 & $28 \%$ & 0 & $0 \%$ & 17 & $68 \%$ \\
\hline distinct & 0 & $0 \%$ & 1 & $4 \%$ & 1 & $4 \%$ & 23 & $92 \%$ \\
\hline groomed & 6 & $24 \%$ & 12 & $48 \%$ & 2 & $8 \%$ & 5 & $20 \%$ \\
\hline
\end{tabular}




\begin{tabular}{|c|c|c|c|c|c|c|c|c|}
\hline mangle & 1 & $4 \%$ & 17 & $68 \%$ & 0 & $0 \%$ & 7 & $28 \%$ \\
\hline cunning & 7 & $28 \%$ & 15 & $60 \%$ & 0 & $0 \%$ & 3 & $12 \%$ \\
\hline jaded & 17 & $68 \%$ & 7 & $28 \%$ & 1 & $4 \%$ & 0 & $0 \%$ \\
\hline pristine & 9 & $36 \%$ & 14 & $56 \%$ & 0 & $0 \%$ & 2 & $8 \%$ \\
\hline lapsed & 5 & $20 \%$ & 8 & $32 \%$ & 1 & $4 \%$ & 11 & $44 \%$ \\
\hline awe-inspiring & 1 & $4 \%$ & 16 & $64 \%$ & 0 & $0 \%$ & 8 & $32 \%$ \\
\hline gracious & 2 & $8 \%$ & 5 & $20 \%$ & 1 & $4 \%$ & 17 & $68 \%$ \\
\hline plummeted & 2 & $8 \%$ & 22 & $88 \%$ & 0 & $0 \%$ & 1 & $4 \%$ \\
\hline compromise & 0 & $0 \%$ & 2 & $8 \%$ & 0 & $0 \%$ & 23 & $92 \%$ \\
\hline catch on & 3 & $12 \%$ & 2 & $8 \%$ & 1 & $4 \%$ & 19 & $76 \%$ \\
\hline outgrowth & 2 & $8 \%$ & 6 & $24 \%$ & 2 & $8 \%$ & 15 & $60 \%$ \\
\hline butting in & 2 & $8 \%$ & 11 & $44 \%$ & 1 & $4 \%$ & 11 & $44 \%$ \\
\hline undeniable & 1 & $4 \%$ & 4 & $16 \%$ & 1 & $4 \%$ & 19 & $76 \%$ \\
\hline flirting & 0 & $0 \%$ & 8 & $32 \%$ & 0 & $0 \%$ & 17 & $68 \%$ \\
\hline facet & 10 & $40 \%$ & 5 & $20 \%$ & 2 & $8 \%$ & 8 & $32 \%$ \\
\hline confinement & 1 & $4 \%$ & 16 & $64 \%$ & 0 & $0 \%$ & 8 & $32 \%$ \\
\hline creep in & 3 & $12 \%$ & 12 & $48 \%$ & 0 & $0 \%$ & 10 & $40 \%$ \\
\hline watertight & 2 & $8 \%$ & 18 & $72 \%$ & 1 & $4 \%$ & 4 & $16 \%$ \\
\hline grabs me & 0 & $0 \%$ & 7 & $28 \%$ & 0 & $0 \%$ & 18 & $72 \%$ \\
\hline sparse & 1 & $4 \%$ & 21 & $84 \%$ & 0 & $0 \%$ & 3 & $12 \%$ \\
\hline restrain & 2 & $8 \%$ & 18 & $72 \%$ & 0 & $0 \%$ & 5 & $20 \%$ \\
\hline prone to & 1 & $4 \%$ & 15 & $60 \%$ & 0 & $0 \%$ & 9 & $36 \%$ \\
\hline track down & 4 & $16 \%$ & 14 & $56 \%$ & 0 & $0 \%$ & 7 & $28 \%$ \\
\hline craving & 1 & $4 \%$ & 9 & $36 \%$ & 2 & $8 \%$ & 13 & $52 \%$ \\
\hline alludes to & 4 & $16 \%$ & 6 & $24 \%$ & 1 & $4 \%$ & 14 & $56 \%$ \\
\hline gifted & 2 & $8 \%$ & 9 & $36 \%$ & 0 & $0 \%$ & 14 & $56 \%$ \\
\hline fuss & 6 & $24 \%$ & 13 & $52 \%$ & 1 & $4 \%$ & 5 & $20 \%$ \\
\hline proponents & 15 & $60 \%$ & 7 & $28 \%$ & 2 & $8 \%$ & 1 & $4 \%$ \\
\hline revolves around & 4 & $16 \%$ & 5 & $20 \%$ & 1 & $4 \%$ & 15 & $60 \%$ \\
\hline adhere to & 6 & $24 \%$ & 9 & $36 \%$ & 1 & $4 \%$ & 9 & $36 \%$ \\
\hline ruled out & 14 & $56 \%$ & 6 & $24 \%$ & 1 & $4 \%$ & 4 & $16 \%$ \\
\hline staples & 24 & $96 \%$ & 0 & $0 \%$ & 0 & $0 \%$ & 1 & $4 \%$ \\
\hline ravaged & 13 & $52 \%$ & 6 & $24 \%$ & 2 & $8 \%$ & 4 & $16 \%$ \\
\hline
\end{tabular}




\begin{tabular}{|l|c|c|c|c|c|c|c|c|}
\hline blip & 16 & $64 \%$ & 3 & $12 \%$ & 3 & $12 \%$ & 3 & $12 \%$ \\
\hline swiftly & 11 & $44 \%$ & 4 & $16 \%$ & 3 & $12 \%$ & 7 & $28 \%$ \\
\hline side effects & 2 & $8 \%$ & 5 & $20 \%$ & 1 & $4 \%$ & 17 & $68 \%$ \\
\hline mucking up & 20 & $80 \%$ & 4 & $16 \%$ & 0 & $0 \%$ & 1 & $4 \%$ \\
\hline better off & 1 & $4 \%$ & 8 & $32 \%$ & 2 & $8 \%$ & 14 & $56 \%$ \\
\hline
\end{tabular}

Statistical analyses were performed using Statistical Packages for Social Sciences (SPSS) software. The number of correct answers in the pre and posttest were tested for significant differences by means of a t-test. The null hypothesis was there is no difference between students' pre and posttest scores. Table 4 presents the results.

Table 4: Vocabulary gains by item

\begin{tabular}{|c|c|c|c|c|c|c|}
\hline Item & $\begin{array}{c}\text { Pretest } \\
\text { Correct Answers }\end{array}$ & $\begin{array}{c}\text { Posttest } \\
\text { Correct Answers }\end{array}$ & $p 1$ & $p 2$ & $t_{c}$ & $\mathrm{~T}_{0.05,48}=1.68$ \\
\hline 1 & 15 & 24 & 0.60 & 0.96 & 4.35 & * \\
\hline 2 & 4 & 25 & 0.16 & 1.00 & 8.51 & * \\
\hline 3 & 11 & 23 & 0.44 & 0.92 & 5.14 & * \\
\hline 4 & 14 & 24 & 0.56 & 0.96 & 4.68 & * \\
\hline 5 & 18 & 23 & 0.72 & 0.92 & 2.60 & * \\
\hline 6 & 20 & 25 & 0.80 & 1.00 & 3.33 & * \\
\hline 7 & 6 & 23 & 0.24 & 0.92 & 6.89 & * \\
\hline 8 & 17 & 24 & 0.68 & 0.96 & 3.64 & * \\
\hline 9 & 24 & 24 & 0.96 & 0.96 & 0.00 & \\
\hline 10 & 7 & 17 & 0.28 & 0.68 & 4.00 & * \\
\hline 11 & 7 & 24 & 0.28 & 0.96 & 7.00 & * \\
\hline 12 & 3 & 18 & 0.12 & 0.72 & 6.08 & * \\
\hline 13 & 1 & 7 & 0.04 & 0.28 & 3.27 & * \\
\hline 14 & 2 & 16 & 0.08 & 0.64 & 5.83 & * \\
\hline 15 & 12 & 19 & 0.48 & 0.76 & 2.88 & * \\
\hline 16 & 8 & 24 & 0.32 & 0.96 & 6.67 & * \\
\hline 17 & 18 & 22 & 0.72 & 0.88 & 2.00 & * \\
\hline
\end{tabular}




\begin{tabular}{|l|c|c|r|r|r|}
\hline 18 & 1 & 23 & 0.04 & 0.92 & 8.81 \\
\hline 19 & 23 & 25 & 0.92 & 1.00 & 2.04 \\
\hline 20 & 20 & 21 & 0.80 & 0.84 & 0.52 \\
\hline 21 & 17 & 21 & 0.68 & 0.84 & 1.87 \\
\hline 22 & 12 & 22 & 0.48 & 0.88 & 4.29 \\
\hline 23 & 20 & 23 & 0.80 & 0.92 & 1.73 \\
\hline 24 & 17 & 25 & 0.68 & 1.00 & 4.36 \\
\hline 25 & 10 & 13 & 0.40 & 0.52 & 1.20 \\
\hline 26 & 8 & 24 & 0.32 & 0.96 & 6.67 \\
\hline 27 & 10 & 22 & 0.40 & 0.88 & 5.00 \\
\hline 28 & 5 & 22 & 0.20 & 0.88 & 6.82 \\
\hline 29 & 18 & 25 & 0.72 & 1.00 & 4.03 \\
\hline 30 & 3 & 24 & 0.12 & 0.96 & 8.43 \\
\hline 31 & 5 & 23 & 0.20 & 0.92 & 7.25 \\
\hline 32 & 9 & 24 & 0.36 & 0.96 & 6.33 \\
\hline$*$
\end{tabular}$*$

An alpha level of .05 was used for all statistical tests.

Does not reject the null hypothesis 
There is evidence to reject the null hypothesis in 42 of the items $(87.5 \%)$. Of the remaining 6 items (12\%), it is important to notice that all the students already knew the word distinct in item 9 at the time of the pretest, and 20 knew catch on in item 20. This fact explains the results. However, for item 25, facet, there was no significant difference in the level of acquisition in spite of the fact that the word is a cognate. The rest of the nonsignificant items, 42, 44 and 45 (staples, blip, and swiftly) were not studied in class. The results of the analysis of the pre and posttest seem to indicate that the systematic and explicit teaching of vocabulary in this particular group was effective. At the end of the course, most of the students were able to recognize most of the words. In fact, 31 out 39 of the words explicitly taught were recognized by at least $80 \%$ of the students. What is more, all of the students got 5 of these words correct and 9 words were missed by only one student. Therefore, it can be concluded that overall the vocabulary items were acquired during the semester

Tables 5, 6 and 7 focus on the learners' performance. They present the results of 3 sets of t-tests performed on each student's pre and posttest scores. Table 5 includes all the items, Table 6 includes only the 39 items studied in class, and Table 7 includes the 9 items that were not studied.

Table 5: Students' scores in pre and posttest: all the items

\begin{tabular}{|c|c|c|c|c|c|c|}
\hline Student & $\begin{array}{l}\text { Pretest } \\
48 \text { items }\end{array}$ & $\begin{array}{l}\text { Posttest } \\
48 \text { items }\end{array}$ & $p 1$ & p2 & & $t_{0.05,94}=1.66$ \\
\hline$A$ & 8.1 & 9.4 & 0.81 & 0.94 & 1.93 & * \\
\hline$B$ & 5.0 & 8.7 & 0.50 & 0.87 & 3.90 & * \\
\hline C & 3.7 & 8.7 & 0.37 & 0.87 & 5.05 & * \\
\hline$D$ & 4.6 & 9.2 & 0.46 & 0.92 & 4.87 & * \\
\hline$E$ & 4.2 & 8.9 & 0.42 & 0.89 & 4.84 & * \\
\hline$F$ & 1.9 & 8.3 & 0.19 & 0.83 & 6.27 & * \\
\hline$G$ & 4.8 & 8.3 & 0.48 & 0.83 & 3.61 & * \\
\hline $\mathrm{H}$ & 3.3 & 7.9 & 0.33 & 0.79 & 4.54 & * \\
\hline I & 6.9 & 8.7 & 0.69 & 0.87 & 2.13 & * \\
\hline $\mathrm{J}$ & 8.1 & 8.7 & 0.81 & 0.87 & 0.80 & \\
\hline $\mathrm{K}$ & 5.0 & 8.3 & 0.50 & 0.83 & 3.43 & * \\
\hline L & 1.4 & 7.3 & 0.14 & 0.73 & 5.83 & * \\
\hline
\end{tabular}




\begin{tabular}{|l|l|l|l|l|l|l|}
$\mathrm{M}$ & 5.4 & 7.9 & 0.54 & 0.79 & 2.59 & * \\
\hline $\mathrm{N}$ & 6.0 & 7.9 & 0.60 & 0.79 & 2.02 & $*$ \\
\hline $\mathrm{O}$ & 3.9 & 7.7 & 0.39 & 0.77 & 3.77 & $*$ \\
\hline $\mathrm{P}$ & 5.0 & 8.1 & 0.50 & 0.81 & 3.19 & $*$ \\
\hline $\mathrm{Q}$ & 2.1 & 7.5 & 0.21 & 0.75 & 5.30 & $*$ \\
\hline $\mathrm{R}$ & 3.9 & 7.3 & 0.39 & 0.73 & 3.36 & $*$ \\
\hline $\mathrm{S}$ & 3.7 & 7.3 & 0.37 & 0.73 & 3.55 & $*$ \\
\hline $\mathrm{T}$ & 5.6 & 6.9 & 0.56 & 0.69 & 1.32 & \\
\hline $\mathrm{U}$ & 2.3 & 6.7 & 0.23 & 0.67 & 4.33 & $*$ \\
\hline $\mathrm{V}$ & 1.9 & 6.9 & 0.19 & 0.69 & 4.93 & $*$ \\
\hline W & 2.9 & 6.4 & 0.29 & 0.64 & 3.44 & $*$ \\
\hline $\mathrm{X}$ & 2.7 & 5.8 & 0.27 & 0.58 & 3.07 & * \\
\hline $\mathrm{Y}$ & 4.4 & 5.8 & 0.44 & 0.58 & 1.37 & \\
\hline
\end{tabular}

An alpha level of .05

Does not reject null hypothesis

There is evidence to reject the null hypothesis for $22(88 \%)$ of the students. Their scores were significantly higher in the posttest than in the pretest, even when nine of the words were never taught in class. Table 6 presents the results of the second set of t-tests.

Table 6: Students' scores in pre and posttest: 39 items explicitly taught

\begin{tabular}{|c|c|c|c|c|c|c|}
\hline Student & $\begin{array}{c}\text { Pretest } \\
30 \\
\text { items }\end{array}$ & $\begin{array}{l}\text { Posttest } \\
39 \text { items }\end{array}$ & p1 & $P 2$ & $\mathbf{t}_{\mathrm{c}}$ & $t_{0.05,76}=1.68$ \\
\hline$A$ & 8.2 & 9.7 & 0.82 & 0.97 & 2.16 & * \\
\hline B & 5.1 & 9.7 & 0.51 & 0.97 & 4.63 & * \\
\hline C & 3.6 & 9.7 & 0.36 & 0.97 & 5.71 & * \\
\hline $\mathrm{D}$ & 4.3 & 9.5 & 0.43 & 0.95 & 4.96 & * \\
\hline$E$ & 4.9 & 9.2 & 0.49 & 0.92 & 4.16 & * \\
\hline$F$ & 2.1 & 9.2 & 0.21 & 0.92 & 6.32 & * \\
\hline G & 5.9 & 9.2 & 0.59 & 0.92 & 3.39 & * \\
\hline $\mathrm{H}$ & 3.6 & 9.2 & 0.36 & 0.92 & 5.15 & * \\
\hline
\end{tabular}




\begin{tabular}{|c|c|c|c|c|c|c|}
\hline I & 8.5 & 9.0 & 0.85 & 0.90 & 0.67 & \\
\hline $\mathrm{J}$ & 8.2 & 9.0 & 0.82 & 0.90 & 1.02 & \\
\hline $\mathrm{K}$ & 5.6 & 9.0 & 0.56 & 0.90 & 3.38 & * \\
\hline $\mathrm{L}$ & 1.5 & 9.0 & 0.15 & 0.90 & 6.63 & * \\
\hline$M$ & 5.4 & 8.7 & 0.54 & 0.87 & 3.20 & * \\
\hline $\mathrm{N}$ & 6.4 & 8.7 & 0.64 & 0.87 & 2.36 & * \\
\hline 0 & 4.3 & 8.7 & 0.43 & 0.87 & 4.07 & * \\
\hline$P$ & 5.6 & 8.5 & 0.56 & 0.85 & 2.81 & * \\
\hline $\mathrm{Q}$ & 2.3 & 7.9 & 0.23 & 0.79 & 4.95 & * \\
\hline $\mathrm{R}$ & 3.8 & 7.9 & 0.38 & 0.79 & 3.67 & * \\
\hline$S$ & 4.1 & 7.9 & 0.41 & 0.79 & 3.43 & * \\
\hline$T$ & 5.9 & 7.7 & 0.59 & 0.77 & 1.70 & * \\
\hline$U$ & 2.6 & 7.7 & 0.26 & 0.77 & 4.51 & * \\
\hline $\mathrm{V}$ & 2.0 & 7.4 & 0.20 & 0.74 & 4.78 & * \\
\hline W & 3.3 & 7.2 & 0.33 & 0.72 & 3.45 & * \\
\hline$x$ & 2.6 & 6.9 & 0.26 & 0.69 & 3.80 & * \\
\hline$Y$ & 4.9 & 6.2 & 0.49 & 0.62 & 1.16 & \\
\hline
\end{tabular}

Alpha level of .05

Does not reject null hypothesis

When individual performance is observed, once again, there is evidence to reject the null hypothesis for all but 3 of the students (88\%). Of these 3 students, 2 are the same as in Table 5: student $\mathrm{J}$ and student $\mathrm{Y}$. In both cases, the $t$-test performed on student J's scores was not significant. Although his initial performance was excellent, this learner made very little progress throughout the semester. This behavior contrasts with that of other students such as A, who also knew most of the words from the start but who also showed significant gains. Student $\mathrm{Y}$, on the other hand, had very limited knowledge of the words at the beginning of the course, and in spite of the systematic teaching of vocabulary, showed no significant vocabulary development. The fact that the treatment was successful for most of the class points at other possible explanations for the lack of improvement in these two cases, including poor motivation caused by a class that the learner might have found boring or not challenging, no effort on the learner's part, poor study habits, lack of language aptitude, 
a clash between the teacher's teaching style and the student's learning style among many others.

Table 7: Students' scores in pre and posttest (items not taught explicitly)

\begin{tabular}{|c|c|c|c|c|c|c|}
\hline Student & $\begin{array}{l}\text { Pretest } \\
9 \text { items }\end{array}$ & $\begin{array}{c}\text { Posttest } \\
9 \text { items }\end{array}$ & p1 & $P 2$ & & $t_{0.05,16}=1.75$ \\
\hline A & 7.8 & 7.8 & 0.78 & 0.78 & 0.00 & \\
\hline$B$ & 4.4 & 4.4 & 0.44 & 0.44 & 0.00 & \\
\hline $\mathrm{C}$ & 4.4 & 4.4 & 0.44 & 0.44 & 0.00 & \\
\hline $\mathrm{D}$ & 5.5 & 7.8 & 0.55 & 0.78 & 1.03 & \\
\hline$E$ & 1.1 & 7.8 & 0.11 & 0.78 & 2.86 & * \\
\hline$F$ & 1.1 & 4.4 & 0.11 & 0.44 & 1.57 & \\
\hline G & 0.0 & 4.4 & 0.00 & 0.44 & 2.25 & * \\
\hline $\mathrm{H}$ & 2.2 & 2.2 & 0.22 & 0.22 & 0.00 & \\
\hline I & 7.8 & 7.8 & 0.78 & 0.78 & 0.00 & \\
\hline $\mathrm{J}$ & 7.8 & 7.8 & 0.78 & 0.78 & 0.00 & \\
\hline K & 2.2 & 5.5 & 0.22 & 0.55 & 1.44 & \\
\hline $\mathrm{L}$ & 1.1 & 0.0 & 0.11 & 0.00 & -1.02 & \\
\hline$M$ & 5.5 & 4.4 & 0.55 & 0.44 & -0.47 & \\
\hline $\mathrm{N}$ & 4.4 & 4.4 & 0.44 & 0.44 & 0.00 & \\
\hline $\mathrm{O}$ & 2.2 & 3.3 & 0.22 & 0.33 & 0.52 & \\
\hline$P$ & 2.2 & 6.7 & 0.22 & 0.67 & 1.92 & * \\
\hline Q & 1.1 & 5.5 & 0.11 & 0.55 & 1.99 & \\
\hline $\mathrm{R}$ & 4.4 & 4.4 & 0.44 & 0.44 & 0.00 & \\
\hline $\mathrm{S}$ & 2.2 & 4.4 & 0.22 & 0.44 & 0.99 & \\
\hline $\mathrm{T}$ & 4.4 & 3.3 & 0.44 & 0.33 & -0.48 & \\
\hline$U$ & 1.1 & 2.2 & 0.11 & 0.22 & 0.63 & \\
\hline V & 1.1 & 4.4 & 0.11 & 0.44 & 1.57 & \\
\hline $\mathrm{W}$ & 1.1 & 3.3 & 0.11 & 0.33 & 1.13 & \\
\hline$X$ & 3.3 & 1.1 & 0.33 & 0.11 & -1.13 & \\
\hline $\mathrm{Y}$ & 2.2 & 4.4 & 0.22 & 0.44 & 0.99 & \\
\hline
\end{tabular}

Alpha level of .05

* There is evidence to reject the null hypothesis. 
When the performance in the 9 items that were not studied in class was analyzed, this time the null hypothesis was rejected for only 3 of the 25 students. In other words, $88 \%$ of the learners did not show significant vocabulary gains. It is not easy to explain the 3 cases in which the vocabulary gains were significant. They might be due to incidental vocabulary learning through extensive reading or to the use of better reading strategies that helped them guess meaning from context. The same explanation is plausible for other smaller gains that were not significant (see Pulido, 2004 for a discussion of incidental vocabulary acquisition).

\subsection{Analysis of the questionnaire}

The following section highlights the most relevant results of the final evaluation of the course. Table 8 summarizes the answers to key questions.

Table 8: Summary of evaluation of the course

How much have your reading skills improved during the semester?

\begin{tabular}{|c|c|c|c|}
\hline A lot $=14$ & Some $=11$ & A little $=0$ & Not at all $=0$ \\
\hline \multicolumn{4}{|c|}{ If your reading skills have improved, what has made you a better reader?* } \\
\hline \multicolumn{4}{|c|}{ Learning new vocabulary. (10 students) } \\
\hline \multicolumn{4}{|c|}{ Learning how to guess the meaning of the words } \\
\hline \multicolumn{4}{|c|}{ I don't have to use the dictionary all the time. } \\
\hline \multicolumn{4}{|c|}{ I am more patient with the book. } \\
\hline \multicolumn{4}{|c|}{ Now I have the habit of reading. } \\
\hline \multicolumn{4}{|c|}{ I pay more attention to word collocations, so I understand better. } \\
\hline \multicolumn{4}{|c|}{ At the beginning I thought I couldn't read a book in English. Now I know I can. } \\
\hline \multicolumn{4}{|c|}{ Are you doing more voluntary reading now? } \\
\hline \multicolumn{2}{|l|}{ Yes $=20$} & \multicolumn{2}{|l|}{ No $=5$} \\
\hline \multicolumn{4}{|c|}{ Is reading more enjoyable now than it was at the beginning of the semester? } \\
\hline \multicolumn{2}{|l|}{ Yes $=23$} & \multicolumn{2}{|l|}{$\mathrm{No}=2$} \\
\hline \multicolumn{4}{|c|}{ Have you learned new vocabulary this semester? } \\
\hline \multicolumn{2}{|l|}{ Yes $=25$} & \multicolumn{2}{|l|}{ No $=0$} \\
\hline
\end{tabular}

*Since this was an open question, the following are sample answers. A few language problems have been corrected. 
The results of the evaluation indicate that learning new vocabulary and strategies to cope with unfamiliar words helped the students read better and enjoy the activity far more. They also acknowledged that there was improvement in their attitude towards reading after they were provided with a group of strategies to read faster and more fluently.

\section{Conclusions}

The results of the t-tests in conjunction with the information collected in the questionnaire and in the evaluation of the course are promising. If teachers are convinced that reading is indispensable for language development to come about and students claim that the greatest obstacle to surmount in the reading process is lack of vocabulary, then language instructors must devote more time to the systematic teaching of lexical items. Apparently, the time invested in this activity pays off. It brings about significant vocabulary development that, according to the students, makes reading easier and more enjoyable. In addition, students reported that adding vocabulary tasks to the reading class provided variety since most of the lessons in the textbook were organized in the same fashion. They welcomed the change. By breaking the monotony of classroom events, learning became more stimulating. Likewise, students appreciated the opportunity to learn language chunks and collocations that they could use in their oral communication and composition classes. They also said that the activities guided them to notice the patterns or the characteristics and special features of the language.

The aforementioned claim that learning new vocabulary was the number one reason why they were able to read better at the end of the term should be interpreted carefully since most likely it does not explain all the factors involved. Undoubtedly, being able to understand and use new words facilitates reading comprehension since the more words one knows, the easier it is to tackle a text and guess meaning from context. However, there is no guarantee that learners are going to encounter the words they have studied in class in future reading tasks. For obvious reasons, it is impossible to anticipate what words are unfamiliar to all the students or are likely to cause misunderstanding. Therefore, we may assume that there is another element underlying their statement: practicing strategies to deal with unfamiliar words empowers students. Learning vocabulary plus learning various reading strategies built their confidence in their learning abilities and increased their expectancy of success. Classroom teachers know that a positive attitude towards any learning task smoothes the way for language acquisition. 


\section{References}

Anderson, N. J. (1999). Exploring second language reading: Issues and strategies. Boston: Heinle \& Heinle Publishers.

Anderson, N. J. (2003). Active: Skills for reading: Book 4. Boston: Heinle \& Heinle Publishers.

Anderson, N. J. (2003). Active: Skills for reading: Book 4, Teacher's manual. Boston: Heinle \& Heinle Publishers.

Benson, M., Benson, E. \& Ilson, R. (1997). The BBI dictionary of English word combinations. Philadelphia: John Benjamins Publishing Company.

Cowie, A. and Mackin, R. (1993). Oxford dictionary of phrasal verbs. New York: Oxford University Press.

Crichton, M. (1970). Five patients. New York: Ballantine Books.

Johns, A. M. (1997). Text, role and context. New York: Cambridge University Press.

Folse, K. S. (2004). Vocabulary myths: applying second language research to classroom teaching. Ann Arbor, Michigan: The University of Michigan Press.

Larsen-Freeman, D. (2001). Teaching grammar. In Marianne Celce-Murcia (Ed.), Teaching English as a second or foreign language. (pp. 251-266). Third Edition. Boston: Heinle \& Heinle.

Lewis, M. (1993). The lexical approach. Hove, UK: Language Teaching Publications.

Lewis, M. (1997). Implementing the lexical approach. Hove, UK: Language Teaching Publications.

Lewis, M. (Ed.). (2000). Teaching collocation: Further developments in the lexical approach. Hove, UK: Language Teaching Publications.

Meara, P. (2002). The rediscovery of vocabulary. Second Language Research. 18 (2): 393-407. New York: Cambridge University Press.

Nagy, W. (1997). On the role of context in first and second language vocabulary acquisition. In Norbert Schmitt \& Michael McCarthy (Eds.), Vocabulary: Description, Acquisition and Pedagogy (pp. 64-83). UK: Cambridge University Press.

Nation, I.S.P. (Ed.). (1994). New ways in teaching vocabulary. Alexandria, VA: Teachers of English to Speakers of Other Languages, Inc.

Nation, I.S.P. (2001). Learning vocabulary in another language. New York: Cambridge University Press.

Pulido, D. (2004). The effect of cultural familiarity on incidental vocabulary acquisition through reading. The Reading Matrix, 4 (2): 20-53. 
Read, J. (2000). Assessing vocabulary. Cambridge: Cambridge University Press.

Schmitt, N. (2000). Vocabulary in language teaching. Cambridge: Cambridge University Press.

Sebold, A. (2002). The lovely bones. Boston: Little, Brown and Company.

Singleton, D. (1999). Exploring the second language mental lexicon. Cambridge: Cambridge University Press.

Thornbury, S. (2002). How to teach vocabulary. Essex: Longman. 